Original Research Paper

\title{
ANTI-MICROBIAL ACTIVITY OF GINGER FLOWER AGAINST SOME CAUSATIVE AGENT OF ACUTE RESPIRATORY INFECTION
}

\author{
Arni Marlinda Zai*, Suandy, Andrico Napolin Lumban Tobing
}

\author{
Faculty of Medicine, Universitas Prima Indonesia, Medan, Indonesia
}

\section{Email Corresponding: \\ arnimarlindazai18@gmail.com}

Page : $15-20$

\section{Keywords:}

ARI, Ginger Flower, Disc Diffusion

\section{Kata Kunci :}

ISPA, Bunga Kecombrang, Difusi Cakram

\begin{abstract}
Various microorganisms such as Streptococcus pneumonia, Haemophilus influenza, Chlamydia spp, and Mycoplasma pneumonia can cause ARI. The ginger flower which contains various phytochemicals that have potential antimicrobial. Recent study was aimed to explore the anti-microbial properties of ginger flower extract. This study was experimental in vitro study with the disc diffusion method. The ethanol extract of Ginger flowers was obtained by maceration method with a ratio of Simplicia to solvent 1:10. Then it concentrated with a rotary evaporator. The ethanol extract of the ginger flower was diluted by DMSO into four concentrations viz. 100\%, 75\%, 50\%, and 25\%. The antimicrobial activity assay used three different types of microbes (Streptococcus pneumonia, Haemophilus influenza, and Candida albicans) different in 3 repetitions. There were significant differences each concentration on the width of clear zone among Streptococcus pneumonia $(P$-value $=0.010)$, Haemophilus influenza $(P$-value $=0.011)$, and Candida albicans $(P$-value $=0.005)$. Also, all concentrations of ginger flower extract showed no significant difference between positive controls; however, significant differences were found for negative controls. Hence, It can be concluded that $25 \%$ of ginger flower extract has been sufficient to inhibit the growth of various tested microorganisms.
\end{abstract}

\begin{abstract}
ABSTRAK
Berbagai mikroorganisme seperti Streptococcus pneumonia, Haemophilus influenza, Chlamydia spp, dan Mycoplasma pneumonia dapat menyebabkan ISPA. Bunga kecombrang mengandung berbagai fitokimia yang berpotensi sebagai antimikroba. Penelitian ini bertujuan untuk mengeksplorasi sifat anti mikroba dari ekstrak bunga kecombrang. Penelitian ini merupakan penelitian eksperimental in vitro dengan metode difusi cakram. Ekstrak etanol bunga kecombrang diperoleh dengan metode maserasi dengan perbandingan simplisia terhadap pelarut 1:10. Kemudian dipekatkan dengan rotary evaporator. Ekstrak etanol bunga kecombrang diencerkan dengan DMSO menjadi empat konsentrasi yaitu. $100 \%, 75 \%, 50 \%$, dan $25 \%$. Uji aktivitas antimikroba menggunakan tiga jenis mikroba (Streptococcus pneumonia, Haemophilus influenza, dan Candida albicans) yang berbeda dalam 3 pengulangan. Terdapat perbedaan yang signifikan setiap konsentrasi pada luas zona bening antara Streptococcus pneumonia (Nilai $\mathrm{P}=0,010$ ), Haemophilus influenza (Nilai $\mathrm{P}=0,011$ ), dan Candida albicans (Nilai $\mathrm{P}=0,005)$. Selain itu, semua konsentrasi ekstrak bunga kecombrang tidak menunjukkan perbedaan yang signifikan antara kontrol positif; Namun, perbedaan signifikan ditemukan untuk kontrol negatif. Dengan demikian, dapat disimpulkan bahwa $25 \%$ ekstrak bunga kecombrang sudah cukup untuk menghambat pertumbuhan berbagai mikroorganisme yang diuji.
\end{abstract}

Published by:

Managed by Faculty of Medicine.

Email: healthytadulako@gmail.com

Phone (WA): +6285242303103

Address:

Jalan Soekarno Hatta Km. 9. City of

Palu, Central Sulawesi, Indonesia mortality and morbidity among infant, childer, and elderly population over the world, especially in the developing country. In Indonesia, the ARI become the highest prevalence due to the high risk of transmission person-to-person that lead to a high rate of death. ARI was transmitted as the airborne 
inhalation transmission by physical contact from hand to inanimate things ${ }^{1234}$.

The usage of antiseptic in the various handwash or hand rub is essential to prevent the transmission of various microorganism. The hand wash and hand rub contain an antiseptic substance that kills several types of microorganism. Hence, these can keep hand hygiene as part of personal hygiene ${ }^{56}$.

Recently, the usage of natural resource as the component of various pharmaceutical products become a new trend, and it was known as back to nature. It is due to less of side effect from the natural resources. One of them was banana's stem that has been reported whether it has an antibacterial effect against Staphylococcus aureus 7 .

Another natural that also has antibacterial effects was Ginger flower which has the binomial name as Etlingera elatior. Ginger flower widely used as the traditional food ingredients in bataknese culture. Moreover, several studies have been performed to explore the antibacterial effect of the ginger flower. These studies reported that Ginger flower has an antibacterial effect against some strain of bacteria like Bacillus cereus, Escherichia coli, and Salmonella enterica serovar Typhi, is due to the ginger flower was enriched by some phytochemicals like phenol, tannin, flavonoid, and saponin. These phytochemicals in ginger flower also have other pharmacological properties like anti-fungal, antioxidants, and antiinflammatory ${ }^{8,910}$.

Based on the facts above, this become important looking for the antibacterial effect of Ginger flower as the indigenous plant from Indonesia in back to nature trends. Hence, this study was designed to explore the antibacterial effect of Ginger flower to several microorganisms which were the cause of ARI viz. Streptococcus pneumoniae as the positive-gram bacteria, Haemophilus influenzae as negative-gram bacteria, and Candida albicans as fungal.

\section{METHODS}

This study was used some materials included Etanol 96\%, DMSO, Dettol ® as standard, ginger flower (Etlingera elatior), some strains of microorganism that have been cultured in the
Microbiology Laboratory of Universitas Prima Indonesia (Streptococcus pneumonie, Haemophylus influenzae, and Candida albicans) Nutrient agar (NA), media Trypticase Soy Agar (TSA), media Potato Dextrose Agar, the reagent for phytochemical screening, $70 \%$ alcohol, aquabidest, and Dimethyl Sulfide Oxide (DMSO).

This study was used Ginger flower that was obtained from a traditional market in Berastagi Town, district of Karo Regency. The ginger flower was identified in Herbarium of Medanese in the University of North Sumatera.

Amount of $2 \mathrm{~kg}$ Ginger flower was washed, then it was dried under $40^{\circ} \mathrm{C}$ for three days. After that, it meshed into Simplicia powder by blending them. Moreover, the simplicia powder was macerated by soaked into ethanol as the solvent in 1:10 ratio, and this maceration was repeated two times. It was filtered, and the filtrate was evaporated by rotary evaporator. The concentrated form was dissolved by DMSO into several concentrations viz. $25 \%, 50 \%, 75 \%$, and $100 \%{ }^{11}$.

The method that was used to phytochemical screening in this study was adopted from Suandy et al. (2018) included saponin, flavonoid, triterpenoid/steroid, glycoside, and alkaloid ${ }^{12}$.

Disc diffusion methods performed to evaluate the anti-microbial effect. Either NA or PDA was poured into some plates for anti-microbial assay. The strain of bacterial and fungal was swabbed by cotton swab into NA and PDA, respectively. After that, placed dissolved extract, antiseptic (Dettol (B), and blank disc into NA or PDA plate surface, and then all NA and PDA plate incubated at $37^{\circ} \mathrm{C}$ for 48 hours. After 48 hours, the plates would show clear zone as the inhibition zone, and calliper measured the width of the clear zone in millimetres ${ }^{11,13}$.

All data were analyzed using the descriptive and inferential statistic. Descriptive analysis was looking for central tendency and disperse of inhibition zone diameter based on their concentration followed by normality test using Shapiro-Wilk. If the data distribution was normal, the data were analyzed by one way ANOVA, instead of Kruskal-Wallis. 


\section{RESULT}

The phytochemical screening against the extract of Ginger flower was shown by the following table (Table 1).

Table 1. Phytochemical Screening from Extract from Ginger Flower

\begin{tabular}{ll}
\hline Phytochemicals & Results \\
\hline Saponin & + \\
Flavonoid & + \\
Triterpenoid/steroid & + \\
Glycoside & + \\
Alkaloid & + \\
\hline
\end{tabular}

According to table 1 above, it mean that the ethanol extract of Ginger flower contains various phytochemicals like saponin, flavonoid, triterpenoid, steroid, glycoside, and alkaloid. These phytochemicals were responsible for various pharmacology properties of the ginger flower as the antibacterial, antioxidant, etc. ${ }^{1415}$.

The anti-microbial activity of ethanol extract from ginger flower against the Streptococcus pneumonia was shown by the clear zone that was observed around the disc. The analysis of clear zone's width was shown by the following table (Table 2).

Table 2. Comparison of Clear Zone from Ethanol Extract of Ginger Flower against Streptococcus pneumonia.

\begin{tabular}{cccc}
\hline \multirow{2}{*}{ Concentration } & \multicolumn{2}{c}{ Width of Clear Zone } & $\begin{array}{c}\text { P- } \\
\text { Value* }\end{array}$ \\
\cline { 2 - 3 } Median & Min-Max & Va.80- & \\
$25 \%^{\mathrm{a}}$ & 10.90 & 11.10 & \\
& & $12.10-$ & \\
$50 \%^{\mathrm{a}}$ & 12.20 & 12.30 & \\
& & $13.10-$ & \\
$75 \%^{\mathrm{a}}$ & 13.60 & 14.10 & 0.010 \\
& & $16.20-$ & \\
$100 \%^{\mathrm{a}}$ & 16.30 & 17.10 & \\
& & $11.00-$ & \\
Positive $^{\mathrm{a}}$ & 13.20 & 13.80 & \\
Negative & 6.00 & 0 & \\
\hline
\end{tabular}

* P-value obtained from Kruskal-Wallis; ${ }^{\text {a There is }}$ a significant difference to the negative control group
According to the table above, it can be seen that there are significant differences in each concentration on the formation of a clear zone against Streptococcus pneumonia. It is shown by the $\mathrm{P}$-value $=0.010$ (P-Value lower than 0.05); the difference is seen in each treatment group against the negative control.

The anti-microbial activity of ethanol extract from ginger flower against Haemophilus influenza was shown by the clear zone that was observed around the disc, and the analysis of clear zone's width was shown by the following table (Table 3 ).

Table 3. Comparison of Clear Zone from Ethanol Extract of Ginger Flower against Haemophilus influenza

\begin{tabular}{|c|c|c|c|}
\hline \multirow{2}{*}{ Concentration } & \multicolumn{2}{|c|}{ Width of Clear Zone } & \multirow{2}{*}{$\begin{array}{c}\text { P- } \\
\text { Value* }\end{array}$} \\
\hline & Median & Min-Max & \\
\hline $25 \%^{\mathrm{a}}$ & 10.80 & $\begin{array}{c}10.70- \\
10.90\end{array}$ & \multirow{6}{*}{0.011} \\
\hline $50 \%^{\mathrm{a}}$ & 14.70 & $\begin{array}{c}14.20- \\
14.90\end{array}$ & \\
\hline $75 \%{ }^{\mathrm{a}}$ & 15.70 & $\begin{array}{c}15.00- \\
15.80\end{array}$ & \\
\hline $100 \%^{\mathrm{a}}$ & 16.80 & $\begin{array}{c}16.00- \\
16.90\end{array}$ & \\
\hline Positive $^{a}$ & 15.80 & $\begin{array}{c}12.80- \\
16.80\end{array}$ & \\
\hline Negative & 6.00 & 0 & \\
\hline $\begin{array}{l}\text { * } \mathrm{P} \text {-value obtain } \\
\text { a significant di } \\
\text { group }\end{array}$ & $\begin{array}{l}\text { from } \mathrm{Kr} \\
\text { rence to }\end{array}$ & $\begin{array}{l}\text { kall-Wallis } \\
\text { the negativ }\end{array}$ & $\begin{array}{l}\text { There is } \\
\text { contro }\end{array}$ \\
\hline
\end{tabular}

According to table above, it can be seen that there are significant differences in each concentration on the formation of a clear zone against Haemophilus influenza. It can be seen from the P-value $=0.011$ (P-Value lower than 0.05); the difference is seen in each treatment group against the negative control.

The anti-microbial activity of ethanol extract from ginger flower against the Candida albicans was shown by the clear zone that was observed around the disc, and the analysis of clear zone's width as shown by the following table (Table 4). 
Table 4. Comparison of Clear Zone from Ethanol Extract of Ginger Flower against Candida albicans

\begin{tabular}{llll}
\hline \multirow{2}{*}{ Concentration } & \multicolumn{2}{l}{ Width of Clear Zone } & \multicolumn{1}{l}{ P- } \\
& Median & Min-Max & Value* \\
\hline $25 \%^{\mathrm{a}}$ & 20.00 & $18.70-$ & \\
& & 20.10 & \\
$50 \%^{\mathrm{a}}$ & 20.80 & $20.50-$ & \\
& & 20.90 & \\
$75 \%^{\mathrm{a}}$ & 22.00 & $21.90-$ & \\
& & 22.20 & 0.005 \\
$100 \%^{\mathrm{a}}$ & 25.00 & $24.90-$ & \\
& & 25.20 & \\
Positive $^{\mathrm{a}}$ & 11.10 & $11.00-$ & \\
Negative $^{2}$ & 6.00 & 11.30 & \\
\hline
\end{tabular}

* P-value obtained from Kruskall-Wallis; ${ }^{a}$ There is a significant difference to the negative control group

According to table above, it can be seen whether there are significant differences in each concentration on the formation of a clear zone against Candida albicans. It is shown by the Pvalue $=0.005$ (P-Value lower than 0.05); the difference is seen in each treatment group against the negative control.

\section{DISCUSSION}

The result of this study answered the purpose of recent study that explores the anti-microbial properties of the ginger flower against causes of ARI. According to the result of this study, at least the lowest concentration of ginger flower extract has shown a significant anti-microbial effect against the causative agent of ARI than the negative control group. Moreover, the lowest concentration of ginger flower extract was also an anti-microbial effect as well as the positive control group.

According to the central tendency from the width of the clear zone formed by each antimicrobial assay, the anti-microbial assay was classified according to Greenwood classification (Tabel 5). The 25\%-75\% ethanol extract of ginger flower weakly inhibited the growth of bacteria (Streptococcus pneumonia and Haemophilus influenza). Meanwhile, the highest concentration (100\%) showed strongly enough to inhibit the growth of tested bacteria. However, ginger flower showed better anti-fungal effect than the antibacterial effect. The ginger flower showed a very strong inhibition for the growth of fungal (Candida albicans) at all concentrations ${ }^{16}$.

Table 5. Greenwood Classification

\begin{tabular}{|c|c|c|}
\hline $\begin{array}{r}\text { Width of } \\
\text { zone (mm) }\end{array}$ & Clear & $\begin{array}{l}\text { Antimicrobial } \\
\text { activity }\end{array}$ \\
\hline Higher 20 & & Strong \\
\hline 16 to 20 & & Quietly strong \\
\hline 10 to 15 & & Weak \\
\hline Lower 10 & & none \\
\hline
\end{tabular}

The anti-microbial effect of ginger flower may be due to the presence of tannin, terpenoid, saponin, and flavonoid ${ }^{14}$. Pramiastuti et al. (2019) and Kusriani et al. (2017) reported that ginger flower had high total phenolic content (48.223 GAE/Gram) that lead to the very potent antioxidant activity ${ }^{17} 18$

\section{CONCLUSION}

At the lowest concentration, ethanol extract of ginger flower showed anti-microbial activity against causes of ARI viz. Streptococcus pneumonia, Haemophilus influenza, and Candid albicans as well as the positive control groups.

\section{ACKNOWLEDGMENT}

Thank you to all those who have helped the author in completing this research

\section{DAFTAR PUSTAKA}

1. Dewi IK, Yunianto B. Uji Efektivitas Sediaan Hand Sanitizer Kombinasi Ekstrak Daun Kemangi (Ocimum Sanctum L) Dan Ekstrak Kulit Jeruk Purut (Citrus Hystrix). J Kebidanan dan Kesehat Tradis. 2016;1(2):130-135. doi:10.37341/jkkt.v1i2.74

2. Wahyuningsih S, Raodhah S, Basri S. Infeksi Saluran Pernafasan Akut (ISPA) pada Balita di Wilayah Pesisir Desa Kore Kecamatan Sanggar Kabupaten Bima. Higiene. 2017;3(2):97-105.

3. Sampulawa S, Awan A, Papua DR-JB, 2017 U. Efektivitas ekstrak kloroform 
Caulerpa racemosa dalam menghambat pertumbuhan bakteri patogen penyebab infeksi saluran pernapasan akut (ISPA). $J$ Biol Papua. 2017;9(1):14-19.

4. Pangemanan JI, Sumampouw OJ, Akili RH. Hubungan antara Kondisi Fisik RUmah dengan Kejadian ISPA pada Balita di Wilayah Kerja Puskesmas Melonguane Kabupaten Kepulauan Talaud. J Kesehat Masy. Published online 2016.

5. Kusbiantoro D. Pemberian Health Education Meningkatkan Kemampuan Mencuci Tangan Pada Anak Prasekolah. Surya. 2015;07(02). doi:10.1046/j.13652028.2000.00243.x

6. Doloksaribu BE, Fitri K. Formulasi Sediaan Gel Hand Sanitizer Kombinasi Ekstrak Etanol Daun Kemangi (Ocimum basilicum L.) dan Biji Pepaya (Carica papaya L.). J Dunia Farm. 2017;2(1):5058.

7. Asngad A, Bagas AR. Kualitas pembersih Tangan Hand Sanitizer. April Bagas $R$, Nopitasari. 2018;4(2):61-70. doi:10.23917/bioeksperimen.v4i1.2795

8. Kusumawati E. Uji Aaktivitas Antibakteri Ekstrak Etanol Daun Kecombrang (Etlingera elatior (Jack) R.M. Smith) terhaadap Bateri Bacillus cereus dan Escherichia coli Menggunakan Metode Difsi Sumur. Polhasains. 2016;4(1):2634.

9. Kusumawati E, Supriningrum R, Rozadi R. Uji Aktivitas Antibakteri Ekstrak Etanol Daun Kecombrang Etlingera elatior (Jack) R. M. Sm Terhadap Salmonella typhi. J Ilm Manuntung. 2015;1(1):1-7.

10. Ghasemzadeh A, Jaafar HZE, Rahmat A, Ashkani S. Secondary metabolites constituents and antioxidant, anticancer and antibacterial activities of Etlingera elatior (Jack) R.M.Sm grown in different locations of Malaysia. BMC Complement
Altern $\quad$ Med. 2015;15(1):1-10. doi:10.1186/s12906-015-0838-6

11. Michiko M, Manalu CV, Mutia MS. Uji Efektivitas Ekstrak Etanol Kulit Jeruk Manis (Citrus sinensis) terhadap Bakteri Propionobacteriu acnes. (Jurnal Ilm Mhs Kesehat Masyarakat). 2020;5(1). doi:10.37887/jimkesmas.v5i1.10552

12. Suandy, Girsang E, Nasution AN, Lister INE. Analysis of Protein Content, Spectrophotometry FT-IR, and Antibacterial Effects of Earthworm (Eudriluseugenia). Am Sci Res J Eng Technol Sci. 2020;63(1):94-101.

13. Diana S MP, Annisa E, Mutia MS. Uji Efektivitas Ekstrak Methanol Daun Bangun-Bangun (Coleus amboinicus) terhadap jamur Candida albicans. (Jurnal Ilm Mhs Kesehat Masyarakat). 2020;5(1):34-37.

doi:10.37887/jimkesmas.v5i1.10747

14. Pulungan AF, Octora DD, Sinaga DM. Formulasi Sediaan Salep Antibakteri Ekstrak Etanol Bunga Kecombrang ( Etlingera Elatior ) Terhadap Bakteri Staphylococcus Aureus Formulation of Ointment of Antibactery Ethanol Extract of Torch Ginger ( Etlingera Elatior ) Against Bacteria Staphylococcus a. 2018;1(1):1-5.

15. Suwarni E, Cahyadi KD. Aktivitas Antiradikal Bebas Ekstrak Etaol Bunga Kecombrang (Etlingera elatior) dengan Metode DPPH. J Ilm Medicam. 2016;2(2):39-46.

doi:10.36733/medicamento.v2i2.1095

16. Milah N, Bintari SH, Mustikaningtyas D. Pengaruh Konsentrasi Antibakteri Propolis terhadap Pertumbuhan Bakteri Streptococcus pyogene s secara In Vitro. Life Sci. 2016;5(2):95-99.

17. Pramiastuti O, Zen DA, Prasetiyo BA. Penetapan Kadar Total Fenolik Dan Uji Aktivitasantioksidan Ekstrak Etanol 96\% Daun Kecombrang (Etlingera Elatior) 


Dengan Metode 2,2-Difenil-1-

Pikrilhidazil (DPPH). J Farm Sains

Indones. 2018;1(2):42-55.

18. Kusriani H, Subarnas A, Diantini A, et al. Aktivitas Antioksidan dan Sitotoksik serta Penetapan Kadar Senyawa Fenol Total Ekstrak Daun, Bunga, dan Rimpang Kecombrang (Etlingera elatior). Pharmacy. 2017;14(01):51-63. 